\title{
Limestone Facies And Diagenesis On Tondo Formation At Kaisabu Village Bau-Bau City Southeast Sulawesi Province
}

\author{
Muhammad Chaerul ${ }^{1} *$, La Ode Ngkoimani ${ }^{1}$, Sofyan Sadri ${ }^{1}$ \\ ${ }^{1}$ Universitas Halu Oleo, Kendari, Sulawesi Tenggara. \\ * Corresponding author : "chaerul_geouho@yahoo.co.id \\ Received: Jan 15, 2017. Revised : 18 Jan 2017, Accepted: Feb 20 , 2017, Published: 1 March 2017 \\ DOI: 10.24273/jgeet.2017.2.1.14
}

\begin{abstract}
This study aims to determine the limestone facies and diagenesis on Tondo Formation. The method used was petrographic method bypolarizing microscope. Based on the physical characteristics and biota contained, the carbonate rocks on tondo formation (Tmtl) can be grouped into two facies, namely: Wackestone and Packestone. The diagenesis process that occurred in Tondo Formation research area is microbial micritization, cementation and neomorphism which indicate that the Tondo Formation has existed on diagenetic environment of marine phreatic, meteoric phreatic and meteoric vadose.
\end{abstract}

Keywords: Tondo Formation, Diagenesis, Limestone facies.

\section{Introduction}

The research area is a Tondo Formation (Tmtl) located in one of the areas of Bau-Bau city. Earlier, the researcher describes Tondo Formation (Tmtl) as a formation of Early Miocene - Middle Miocene period. The existence of limestone lithology in the research area is a unique and attractive geological phenomenon to serve as the research object in the final work. The development of highly sensitive limestone that affects the geological condition change will provide excellent information about the geological history. In the research area is included in Tondo Formation (Tmtl), a formation composed of lithology of reef limestone and calcarenite. Mixing between sediment which is a destruction of shallow marine sediments that is rich in benthic foraminifera with deep sea sediments is typical of this formation.The objective of the study is to determine the diagenetic process of limestone facieson Tondo Formation (Tmtl) and the type of limestone faciesbased on the thin section analysis of the research area.

\subsection{Regional Geology}

Buton area is composed by rock unit which can be grouped into Mesozoic and Cenozoic rocks. The group of Mesozoic rocks of Triassic to Upper Cretaceous period and the group of Cenozoic of Miocene and Pleistocene period. Rock group that included in Mesozoic consists of Winto Formation (TRW), Ogena Formation (Jo), Rumu Formation (Jr) and Tobelo Formation (KTT) which are precipitated from the Triassic to the Late Cretaceous period. The sedimentary rock group included in Cenozoic then covers most of Buton area which consists of Tondo Formation (Tmtc), Sampolakosa Formation (Tmps) and Wapulaka Formation (Qpw) precipitated on the Early Miocene to Pleistocene.Buton Stratigraphy according to Davidson (1991) is classified into four tectonostratigraphy events, namely the pre-rift sedimentation consists of Doole Formation, Winto Formation, Ogena Formation; Rift-Drift sedimentation consists of Rumu Formation, Tobelo Formation; Syn and Post Orogenic sedimentation consists of Tondo Formation and Sampolakosa Formation; younger deformation sedimentation (Wapulaka Formation) (Davidson, 1991).

Tectonic events that occur repeatedly cause the older rocks experience several times of structure deformation, so that the older rocks are commonly encountered with the relatively sharp layer slope, while the younger rocks have relatively sharp layer slope than the old rocks. According to Sikumbang, N., et al., (1995) the tectonic event has occurred several times starting from Pre-Eocene, where the tectonic pattern is difficult to determine due to the whole rock has undergone several folding and faulting. The main tectonic movement that forms the structure pattern until now is expected to occur in the Eocene-Oligocene period forming the trending imbrication structure of Northeast-Southwest. The next tectonic activity occurs between the Pliocene-Pleistocene resulting 
in the fold of Pre-Pliocene rocks. The last tectonic activity that occurred since Pleistocene and has continued until now resulted in the uplifting of Buton and Muna island slowly, in time with the formation of reef limestoneon Wapulaka Formation that shows the steps.

\subsection{Diagenesis}

Diagenesis is the process that occurs after the sedimentation process in a rock including chemical and physical process, but this change is not caused by changes in temperature and pressure (metamorphism) (Scholle and (Ulmer - Scholle, 2003 in Flugel, 2004).Diagenesis process is affected by several factors such as pressure, temperature, mineral stability, equilibrium conditions, rate of water influx, time and structure control. Three main processes in diagenesis are dissolution, cementation and replacement. Each process is characterized by different appearance - depends on who interprets the condition of carbonate rocks formation. Here is the process that occur in diagenesis:

a. Microbial Micritization

This process occurs in marine environment, which is formed by the presence of grains drilling activity by endolithic algae, fungi and bacteria around skeletal later the formed hole filled with fine-grained sediments or micrite envelope cement, i.e. micrite surrounding shell. Such organisms' activities are very active, so it will produce a shell that is completely micrited. This is an important process which generally occurs in the environment of stagnant marine phreatic zone and active merine phreatic zone (Longman, 1980).

\section{b. Dissolution}

The process of dissolution is known by their unstable minerals that dissolve and form other stable minerals at the new environment, due to the differences of diagenetic environment. It can occur in vadose zone and freshwater phreatic (Longman, 1980).

c. Cementation

Cementation process is the main diagenetic process in carbonate sediment when the pore water phase has been saturated on the cement phase and there are no kinetic factors that may impede the cement precipitation. This process requires the large circulation of fresh water or sea water. Diagenetic environment is indicated by the different mineralogy and cement fabric depending on the composition of pore water, speed of carbonate supply and precipitation.

d. Neomorphism

Neomorphism is the process of replacement and recrystallization when the change in mineralogy occurred. For example, the coarsening of crystal size on carbonate mud or micrite (aggrading neomorphism) and replacement of aragonite shells and cement by calcite (calcitization) (Tucker and Wright, 1990). This process may occur at the beginning of phreatic freshwater sedimentation and deep burial;

\section{e. Dolomitization}

Dolomitization is the process of replacement of mineral calcite into dolomite caused by the increase of $\mathrm{Mg}$ content in carbonate rocks. Factors that accelerate the dolomite precipitation is the magnitude of $\mathrm{Mg} / \mathrm{Ca}$ ratio in minerals, the magnitude of $\mathrm{CO} 2$ content, high temperature and $\mathrm{pH}$, low sulphate content, low salinity content as well as the effect of organic material. Dolomitization process may change into replacement by the precipitation process or in the form of cementation, which may occur in the environment of mixing zoneand deep burial(Morrow. 1982).

f. Compaction

According to Tucker and Wrigth (1990), the compaction process is divided in 2 types, namely:

1) Mechanical compaction occurs when the loading becomes larger which cause cracks in the grains, grains are in contact to each other, porosity reduced.

2) Chemical compaction occurs when the grains are in contact, experience dissolution, which produce suture contacts and concavo-convex contacts.

Studying the diagenesis products which present in a particular environment is the key to predict the tendency to porosity in carbonate rocks. According to Longman (1980) in Tucker and Wright, (1990) the diagenetic environment is divided into five namely:Marine Phreactic Zone, Mixing Zone, Meteoric Phreactic Zone, Meteoric Vadose Zone, and Burial Zone.

\section{Research Methods}

The research area was located in the east of the Bau-Bau city, precisely in the area of Kasiabu Village, Sorawolio Sub District, Bau-Bau city, Southeast Sulawesi Province. This type of research was a kind of field observation study, with the lithological data collection to determine the limestone facies and diagenesis on tondo formation. The research method used was petrographic analysis methodbyusing polarizing microscope

\section{Results and Discussion}

\subsection{Limestone Diagenesis of the Research Area}

Based on the results of the petrographic incision observation from the limestone sample, the diagenesis products contained in limestone on Tondo Formation (Tmtl) are found, namely:

\section{a. Microbial Micritization}

This diagenesis product shows the type of microbial micritizationformed on petrographic incision.Microbial micritizationis a diagenesis product formed at an early stage which is in the marine phreatic environment (Longman, 1980). This product exists in almost all petrographic incision of carbonate rocks where the fossils grains with membranes made of micrite. The membrane 
serves to protect the fossil shells so that it is more resistant to the dissolution. (Figure 1 )

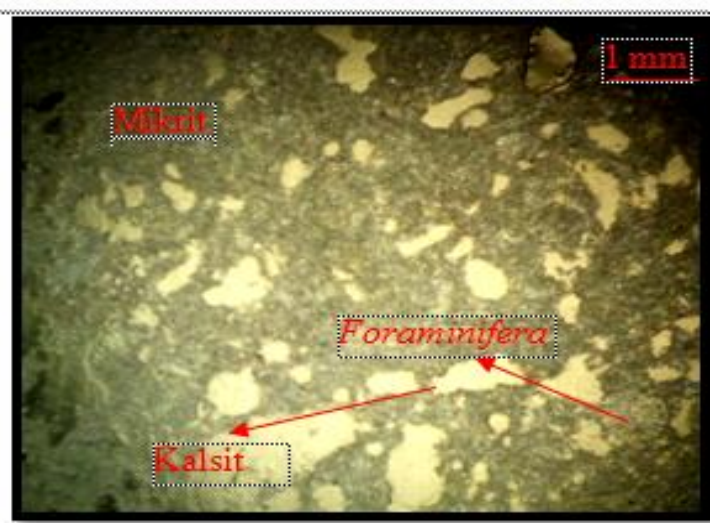

Fig. 1. Micritisasi microbial on Foraminifera Fossil in Limestone (Petrographic Analysis cross nicol with magnifications 10x)

\section{b. Cementation}

This diagenesis product shows the type of cement that formed on petrographic incision. The type of cement at blocky petrographic incision analysis with calcite composition can be formed on a diagenetic environment of meteoric phreatic. (Figure 2)

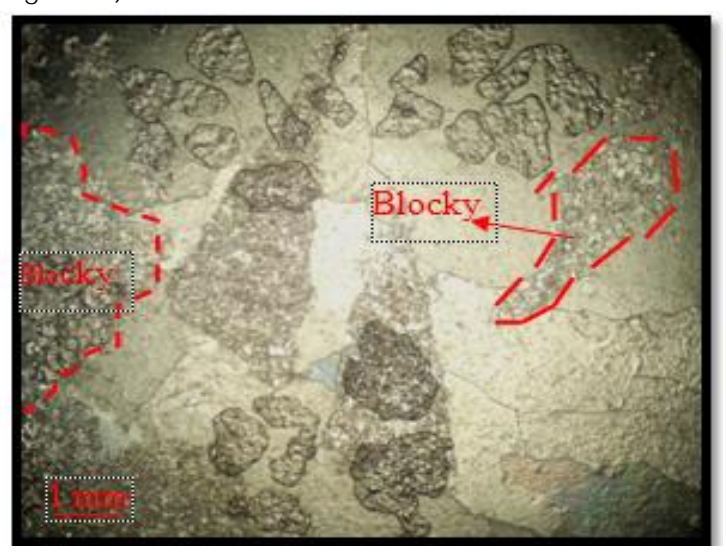

Fig. 2. Blocky Cement in Limestone (Petrographic Analysis cross nicol with magnifications 10x ).

\section{Microbial Micritization}

Petrographic observation at station 3 is a microbial micritization. Micrite is a matrix that is usually dark in color. On the limestone, it is present as very fine grain. Micrite has a grain size of less than 4 micrometers. In the electron microscopy study, it shows that micrite is not homogeneous and shows a rough to fine size with the boundaries between crystals - planar, curved, jagged or irregular shape. Micrite may suffer from alteration and may be replaced by a rough mozaicmicrospar (Tucker, 1991). (Figure 3)

\section{d. Microbial Micritization}

This diagenesis product shows the type of microbial micritizationformed on petrographic incision. This process occurs in marine environment, which is formed by the presence of grain drilling activity by endolithic algae, fungi and bacteria around skeletal.

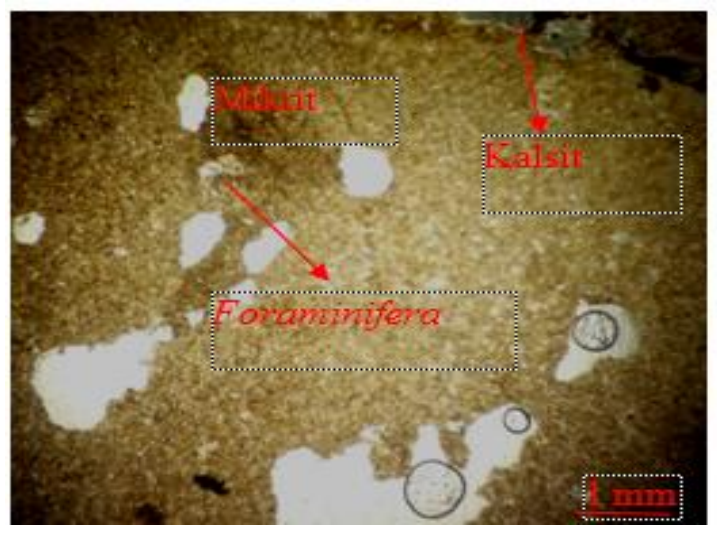

Fig. 3. Micritisasi microbial on Foraminifera Fossil in Limestone (Petrographic Analysis cross nicol with magnifications 10x )

Then the hole formed is filled with finegrained sediments or micrite envelope cement which is the micrite surrounding the shell. Such organisms' activities are very active, so it will produce a shell that is completely micrited. According to Longman 1980, in Tucker and Wright 1990, it is an important process that generally occurs in an environment of stagnant marine phreatic zone and active marinephreatic zone. (Figure 4)

\section{e. Neomorphism}

From the results of the petrographic incision observation what is produced by this process is aggrading neomorphism which is micrite recrystallization into crystals - the large-sized crystal is called microspar. The crystals formed have a more turbid microspar appearance because these crystals come from micrit recrystallization of carbonate mud. Tucker and Wright (1990) state that neomorphism occurred in diagenetic environment of meteoric phreatic and meteoric vadose. Neomorphism is the process of replacement and recrystallization when the change in mineralogy occurred. For example, the coarsening of crystal size on carbonate mud or micrite (aggrading neomorphism) and replacement of aragonite shells and cement by calcite (calcitization) (Tucker, 1990). (Figure 5).

Based on the observations on diagenesis product both from field observations at the outcrop and the petrographic incision analysis it can be interpreted that the diagenetic environment traversed by limestone on Tondo Formation (Tmtl), including the environment of marine phreatic, meteoric phreatic and meteoric vadose.Micrite membranes due to boring organism (microbial micritization) on foraminefera and alga of one identifier of marine phreatic diagenetic environment. The presence of the type of cement of blocky of calcite composition shows the diagenetic environment of meteoric phreatic. Neomorphismmicrite becomes microspar which 
shows the diagenetic environment of meteoric vadose (Figure 6).

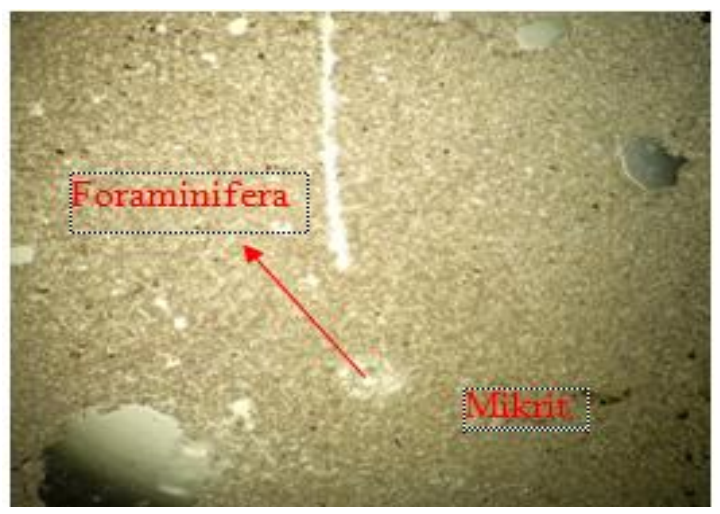

Fig. 4. Micritisasi microbial on Foraminifera Fossil in Limestone (Petrographic Analysis cross nicol with magnifications 10x ).

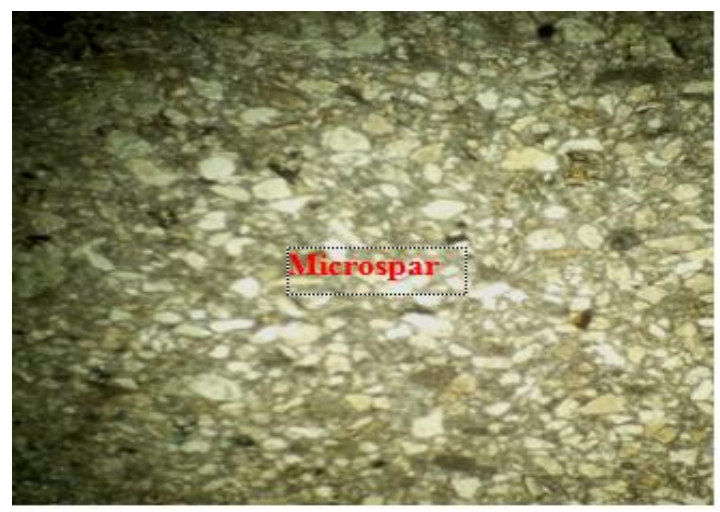

Fig. 5. Changes in the size of the matrix becomes larger microspar (Petrographic Analysis cross nicol with magnifications 10x ).

\subsection{Limestone Facies of the Research Area}

Based on field observations and petrographic incision in the research area, it is concluded that there are two types of limestone facies, namely:

\section{a. Packestone Facies}

This facies found in reef limestoneUnit in the research area which are scattered in the south to the east of Kaisabu area. In this facies zone, the outcrop is characterized by limestone that does not have bedding. The rock characteristics in this zone in the outcrop scale has a moderate sorting with open container, generally the fragments are floating and matrix, generally the color of carbonate mud is light to massive.Based on the observation in the field and the results of petrographic analysis on the rock samples, in the outline it is seen as dominated by Packestonefacies. Packestonefacies contained in this zone has the characteristics that contains fossil fraction in the large enough size namely the abundance of dominant red algae and there are also many shells of foraminifera.Based on petrographic analysis on Packestonefaciesit has the characteristics of abundance carbonate mud and dominated by grain.

\section{b. Wackestone Facies}

This facies found in Calcarenite Unit exists in the research area are scattered in the East to the west part of Kaisabu area. In this facies, the rock outcrop is in grayish fresh color and generally massive and there are pores in it. The components are in the form of carbonate minerals such as calcite and dolomite. Based on the field observation and the results of petrographic analysis of the rock samples, in the outline it is seen as dominated by Wackestonefacies. The facies in this zone has the characteristics that contains an abundance of coral, dominant red algae and there are algae fraction along with other fossil fraction that cannot be identified.Based on the results of petrographic analysis of Wackestonefacies sample, it has the characteristics of very fine grain size and has associations with larger clastic fragments but not dominant.

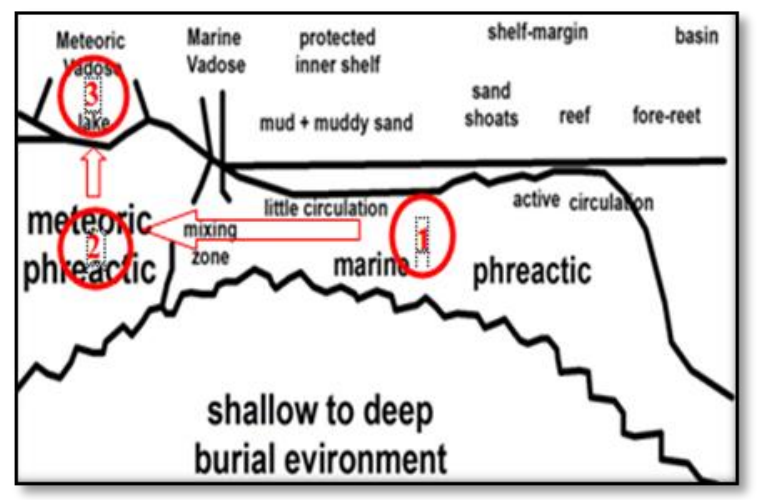

Fig. 6. Scheme diageneis environmental changes that occurred in the study area (Tucker and Wright, 1990) (Petrographic Analysis cross nicol with magnifications 10x)

\section{Conclusions}

Based on the analysis which has been conducted, the author concludes that:

1. The diagenetic process that occur in the research area of Tondo Formation is microbial micritization, cementation and neomorphism which indicate that the Tondo Formation has existed on diagenetic environment of marine phreatic, meteoric phreatic and meteoric vadose.

2. Limestone research area is composed by two facies associations, namely algae facies foramineferapackestone and algae facies foraminefera wackestone.

\section{Acknowledgement}

Authors thank profusely to all parties who has support this research. 


\section{References}

Boggs, S., Jr., 1992, Petrology of sedimentary rocks; Macmillan Pub. Co., New York, 707 p.

Davidson, 1991, Regional Stratigraphy column of Buton Islands.

Dunham, R.J., 1962, Classification of Carbonate Rocks According to Depositional Texture, in Ham, E.E., ed.Classification of Carbonate Rocks, AAPG Memoir I, p. 108-121.

Flugel, E., 2004. Microfacies of Carbonat Rock. Springer, Inc, New York.

Longman, M. W.,1980. Carbonate Diagenetic Textures from Nearsurface Diagenetic Environment,Bulletin AAPG, 64, 461 -485.

Morrow, D. W., 1982. Diagenesis 2 : Dolomite, Part 2. The Geological Association of Canada.

Tucker, M.E., Wright, V.P., 1990. Carbonate Sedimentology. Blackwell Publishing Ltd., pp. 422-467. doi:10.1002/9781444314175.refs 